\title{
Identifikasi Kekeliruan Penggunaan Metode Statistika pada Artikel yang Dimuat di Jurnal OJS Unud
}

\author{
Ni Luh Putu Suciptawati \\ Prodi Matematika, Fakultas MIPA, Universitas Udayana \\ e-mail: suciptawati@unud.ac.id
}

\begin{abstract}
The statistical methods have an important role in scientific research. Use of appropriate statistical methods in analyzing data influences research conclusions. Misuse statistical methods will lead to incorrect conclusions. This paper is aimed to identify the misuse of statistical methods in articles published in the OJS UNUD Journals. We reviewed 107 articles from OJS UNUD Journals published in 2017. The result of this study indicates several misuse statistical methods these included: misuse multiple linear regression analysis, generalize conclusions based on descriptive statistics, inappropriate use of ANOVA, misinterpretation of negative correlation values, use of Chi square test for small samples, use of $t$-test two samples for observations with ordinal scale
\end{abstract}

Keywords: statistical methods, misuse statistical, OJS UNUD Journal

\section{Pendahuluan}

Metode statistika sangat berperan dalam suatu penelitian ilmiah. Ada berbagai metode statistika yang dapat digunakan untuk menyelesaikan masalah-masalah penelitian diantaranya: statistika deskriptif, uji-t, analisa regresi, analisis ragam, tabulasi silang, statistika nonparametrik, dan lain sebagainya. Agar penelitian dapat memberikan kontribusi dan bermanfaat bagi khalayak banyak, pemilihan metode statistika yang tepat dalam analisis data sangatlah diperlukan. Pemilihan metode statistika harus memenuhi berbagai asumsi, skala pengukuran yang digunakan, serta disesuaikan dengan permasalahan dan tujuan penelitian. Dengan berkembangnya paket-paket perangkat lunak statistika sangat membantu peneliti dalam menggunakan metode-metode statistika yang berkaitan dengan penelitian mereka.

(Gardenier \& Resnik, 2002) menyatakan untuk dapat menggunakan metode statistika dengan benar, beberapa hal yang harus diperhatikan diantaranya: informasi tentang variabel yang digunakan (kontinu atau diskrit, gaussian atau bimodal, dll.), informasi tentang proses pengambilan sampel yang digunakan (ukuran sampel, independensi, keacakan, keterwakilan, dll.), serta bagaimana teori dan asumsi yang mendasari. Ketepatan penggunaan statistika sebagai alat analisis data sangat menentukan keakuratan pengambilan kesimpulan, apabila metode statistika yang digunakan dalam penelitian tidak tepat menyebabkan kesalahan dalam penarikan kesimpulan. 
Menurut (Jeon, 2015) pemahaman yang benar tentang pemodelan statistik dan penggunaan metode yang tepat akan mengarah pada interpretasi hasil yang benar, penggunaan pada perubahan kebijakan, serta dapat memberikan kontribusi untuk bidang akademik.

Di perguruan tinggi untuk menyelesaikan studinya mahasiswa diwajibkan melakukan penelitian yang dilaporkan dalam bentuk skripsi, dan mempublikasikannya di jurnal, minimal di jurnal nasional. Tiap-tiap fakultas di Universitas Udayana menyediakan jurnal berbentuk Open Journal System (OJS) sebagai wadah publikasi artikel hasil penelitian mahasiswa. Tidak menutup kemungkinan metode statistika yang digunakan mahasiswa dalam menjawab tujuan penelitian tidak tepat atau kurang layak. Penelitian ini bertujuan mengidentifikasi kekeliruan penggunaan metode statistika yang terdapat pada artikel yang dimuat di jurnal OJS UNUD.

Penelitian mengenai kesalahan penggunaan metode statistika dalam penelitian pernah dilakukan oleh (Thiese, et.al, 2015) mengenai kesalahan-kesalahan yang dilakukan pada penelitian biomedical. Hasil yang diperoleh kesalahan yang sering terjadi diantaranya: kesalahan dalam mendesain metode statistika yang digunakan, kesalahan dalam mendiskripsikan dan mempresentasikan data, kurang tepat dalam menangani pencilan, kesalahan dalam mentransformasi data dan uji kenormalan, kesalahan penerapan uji parametrik dan nonparametrik.

Sejalan dengan penelitian (Thiese, et.al, 2015) penelitian (Wu et al., 2011) pada Chinese Medical Journals menunjukkan bahwa kesalahan terbanyak yang ditemukan ialah pemilihan metode statistik yang tidak tepat. Dikemukakan pula kesalahan tersebut dapat terjadi karena kurangnya pengetahuan dasar para peneliti tentang statistik, menggunakan uji parametrik pada semua data kuantitatif tanpa memperhatikan tipe data. Beberapa studi eksperimental multifaktorial dipecah menjadi serangkaian studi faktor tunggal, yang menghilangkan hubungan intrinsik atau interaksi antara faktorfaktor dan menyebabkan kesimpulan yang salah.

Hasil penelitian (Bahar, et.al, 2018) pada penelitian-penelitian cytopathologi menunjukkan kesalahan yang sering dilakukan peneliti adalah: menggunakan inferensi parametrik untuk data nonparametrik, penggunaan uji Chi kuadrat untuk sampel yang tidak tepat, menggunakan uji independen untuk data berpasangan, menggunakan beberapa uji-t untuk perbandingan multiple group .

Menurut Altman dalam (Wu et al., 2011) beberapa kesalahan penggunaan metode statistika pada artikel-artikel ilmiah sangat umum terjadi, dan metode yang salah tersebut sering dikutip atau digunakan oleh penulis lain, sehingga kesalahan tersebut muncul secara berulang-ulang. 


\section{Metode Penelitian}

Populasi penelitian ini adalah semua artikel ilmiah yang termuat pada jurnal OJS UNUD terbitan tahun 2017. Penentuan sampel pada penelitian ini dilakukan secara purposive sampling, yaitu penarikan sampel dengan pertimbangan. Sebagai sampel diambil jurnal-jurnal yang artikelnya banyak menggunakan metode statistika, untuk itu dipilih 8 jurnal dengan rincian 4 merupakan jurnal ilmu sosial dan 4 jurnal ilmu eksakta. Jurnal yang terpilih ebih jelasnya dapat dilihat pada table 1 .

Tabel 1 Nama Jurnal yang Dipilih Menjadi Sampel Penelitan

\begin{tabular}{|c|c|}
\hline Ilmu Sosial & Ilmu Eksakta \\
\hline 1. E-Jurnal Akuntansi & 1. Buletin Veteriner Udayana \\
\hline 2. E-jurnal Manajemen & 2. Buletin Fisika Udayana \\
\hline 3. Jurnal Kepariwisataan dan Hospitalitas & 3. E-Jurnal Agroekoteknologi Tropika \\
\hline 4. Jurnal Piramida & 4. E-jurnal Medica Udayana \\
\hline
\end{tabular}

Penelitian ini merupakan penelitian deskriptif. Dengan fokus perhatian pada bagaimana penggunaan metode statistika pada artikel ilmiah yang dimuat di Jurnal OJS UNUD, serta megidentifikasi kekeliruan penggunaan metode statistika pada artikel tersebut. Adapun tahapan penelitian yang dilakukan sebagai berikut :

1. Mengumpulkan artikel-artikel jurnal;

2. Memilah artikel yang metode statistikanya sudah benar dan yang masih kurang tepat/salah;

3. Mengidentifikasi kesalahan metode statistika yang terjadi serta memberikan solusi penyelesaian metode statistika yang benar.

\section{Hasil dan Pembahasan.}

\subsection{Gambaran Umum Objek Penelitian}

Artikel yang dimuat di Jurnal OJS UNUD sebagian besar merupakan publikasi hasil penelitian Tugas akhir mahasiswa Universitas Udayana, walaupun ada beberapa jurnal yang juga menerima naskah dari luar institusi Universitas Udayana. Jumlah mahasiswa yang menyelesaikan Tugas akhir pada setiap fakultas atau program studi setiap tahunnya bervariasi, sehingga berpengaruh pada jumlah terbitan jurnal setiap tahunnya. Ada jurnal yang terbit setiap bulan, ada yang terbit setahun 4 kali, ada juga yang terbit setahun hanya 2 kali. Demikian juga jumlah artikel yang dimuat dalam setiap nomor tidak sama. Untuk lebih jelasnya jumlah artikel yang diamati dari setiap jurnal yang dijadikan sampel penelitian dapat dilihat pada Tabel 2 berikut: 
Tabel 2 Gambaran Umum Objek Penelitian

\begin{tabular}{lcc}
\hline \multicolumn{1}{c}{ Nama Jurnal } & $\begin{array}{c}\text { Jumlah Jurnal } \\
\text { pada tahun 2017 }\end{array}$ & Jumlah Artikel \\
\hline Agroekoteknologi Tropika(Volume 6) & 4 & 49 \\
Buletin Fisika (Volume 8) & 2 & 14 \\
Buletin Veteriner Udayana (Volume 9) & 2 & 31 \\
E-jurnal Medica Udayana (Volume 6) & 12 & 134 \\
Jurnal Kepariwisataan dan Hospitalitas (Vol- & 2 & 27 \\
ume 1) & & \\
E-jurnal Manajemen (Volume 6) & 12 & 240 \\
Jurnal Piramida (Volume 13) & 2 & 12 \\
E-Jurna Akuntansi (Volume 20) & 12 & 240 \\
Total & 48 & $\mathbf{7 4 7}$ \\
\hline
\end{tabular}

Karena jumlah artikel pada masing-masing jurnal tidak sama, maka untuk lebih memudahkan pengamatan diputuskan untuk mengambil secara acak satu nomor dari masing-masing jurnal tersebut. Jurnal yang terpilih itulah yang akan dijadikan sampel penelitian untuk diamati penggunaan metode statistikanya. Berikut jurnal-jurnal yang terpilih untuk dijadikan sampel penelitian dapat dilihat pada tabel berikut:

Tabel 3 Jurnal yang dijadikan Sampel penelitian

\begin{tabular}{lcc}
\hline \multicolumn{1}{c}{ Nama Jurnal } & Nomor & Jumlah Artikel \\
\hline Agroekoteknologi Tropika & 4 & 15 \\
Buletin Fisika Udayana & 1 & 7 \\
Buletin Veteriner Udayana (Volume 9) & 1 & 9 \\
E-jurnal Medica Udayana (Volume 6) & 4 & 11 \\
Jurnal Piramida (Volume 13) & 1 & 6 \\
E-jurnal Manjemen (Volume 6) & 2 & 20 \\
Jurnal Kepariwisataan dan Hospitalitas & 1 & 10 \\
(Volume 1) & 2 & 29 \\
E-Jurna Akuntansi (Volume 20) & & $\mathbf{1 0 7}$ \\
Total Artikel & & \\
\hline
\end{tabular}

Metode statistika yang digunakan pada artikel-artikel yang menjadi sampel penelitian beserta jumlahnya dapat dilihat pada table berikut: 
Tabel 4 Metode Statistika pada Artikel yang Diamati

\begin{tabular}{llc}
\hline Nomor & \multicolumn{1}{c}{ Metode } & Jumlah \\
\hline 1 & Regresi Linier berganda & 36 \\
2 & ANOVA & 13 \\
3 & Analisis jalur (Path analysis) & 8 \\
4 & Statistika deskriptif & 7 \\
5 & Analisis Faktor konfirmatorik & 4 \\
6 & Cros sectional & 3 \\
7 & Uji t dua sampel & 3 \\
8 & Tabulasi silang & 3 \\
9 & Chi kuadrat & 2 \\
10 & Uji Kruskal Wallis & 2 \\
11 & Uji Mann Witney dan uji Kruskal Wallis & 2 \\
12 & PLS & 2 \\
13 & SEM & 1 \\
14 & Model logit & 1 \\
15 & Uji Eksak fisher & 1 \\
16 & Uji Kolmogorov-Smirnov & 1 \\
17 & Uji Mc Nemar & 1 \\
18 & Tanpa menggunakan metode statistika & 17 \\
\hline
\end{tabular}

Tabel 4 menunjukkan bahwa analisis regersi linier berganda merupakan metode statistika yang paling sering digunakan untuk menganalisa data penelitian mahasiswa, terutama penelitian untuk mencari pengaruh beberapa perlakuan terhadap suatu respon. Ada 17 artikel tidak menggunakan metode statistika, dari 17 tersebut 15 artikel memiliki rumus/perhitungan khusus, sedangkan 2 artikel merupakan teknik kualitatif sehingga tidak menggunakan metode statistika.

\subsection{Kekeliruan Penggunaan Metode Statistika yang Ditemukan}

Merujuk pada tabel 4 ditemukan 17 metode statistika yang digunakan pada artikel-artikel yang menjadi sampel penelitian. Tampak pula dari 17 metode statistika yang digunakan masih ada penggunaannya yang kurang tepat. Berikut rangkuman kekeliruan penggunaan metode statistika yang ditemukan:

1) Kekeliruan menggunaan analisis regresi linier berganda

Dari artikel-artikel yang diamati kekeliruan yang paling banyak ditemukan adalah dalam penggunaan regersi linier berganda. Ada artikel yang menggunakan analisis regresi linier berganda untuk variabel respon dengan skala pengukuran ordinal (misalnya: sangat tidak puas, tidak puas, puas, sangat puas). Penggunaan regersi linier berganda untuk variabel respon dengan skala nominal ( misalnya: tidak setuju, setuju, sangat setuju). Penggunaan regresi linier berganda pada variabel respon 
maupun variabel prediktor yang masih diukur dalam bentuk indikator-indikator dengan skala likert, atau penggunaan analisis regresi linier untuk variabel prediktor dan variabel respon dalam bentuk kategorik. Kekeliruan lain yang ditemukan adalah pengujian asumsi kenormalan pada variabel-variabel prediktor. Salah satu asumsi yang harus dipenuhi pada analisis regresi linier berganda adalah sisaan yang menyebar normal, seharusnya uji normalitas dilakukan terhadap sisaan bukan variabel independen.

Berikut ini contoh kekeliruan penggunaan metode statistika yang ditemukan pada salah satu artikel.

Penelitian yang bertujuan untuk mengetahui pengaruh sikap $\left(X_{1}\right)$, motivasi $\left(X_{2}\right)$, dan lingkungan $\left(X_{3}\right)$ terhadap niat berwirausaha Mahasiwa $(Y)$. Pengumpulan data menggunakan kuesioner dengan menggunakan skala Likert. Variabel $X_{1}$ dinyatakan dengan 4 item pertanyaan : $X_{11}, X_{12}, X_{13}$ dan $X_{14} ; X_{2}$ terdiri dari 5 item pertanyaan : $X_{21}, X_{22}, X_{23}, X_{24}, X_{25}$; dan $X_{3}$ terdiri dari 3 item pertanyaan yaitu: $X_{31}, X_{32}$, $X_{33}$, demikian juga $Y$ dinyatakan dengan 3 item pertanyaan : $Y_{1}, Y_{2}, Y_{3}$. Jawaban dari setiap pertanyaan diberi skor dari sangat positif sampai sangat negatif (skala ordinal). Metode yang digunakan adalah analisis regresi linier berganda. Rumusan model regresi linier sbb:

$$
Y=\beta_{0}+\beta_{1} X_{1}+\beta_{2} X_{2}+\beta_{3} X_{3}+e
$$

Hipotesis yang digunakan

$H_{1}$ : Sikap berpengaruh positif dan signifikan terhadap niat berwirausaha Mahasiswa

$\mathrm{H}_{2}$ : Motivasi berpengaruh positif dan signifikan terhadap niat berwirausaha Mahasiswa

$H_{3}$ : Lingkungan berpengaruh positif dan signifikan terhadap niat berwirausaha Mahasiswa

Walaupun kesimpulan yang diperoleh sejalan dengan teori-teori ekonomi yang dirujuk, tetapi alat statistika yang digunakan untuk mencapai kesimpulan tersebut kurang tepat atau keliru. Kekeliruan yang tampak adalah penggunaan analisis regresi liner berganda untuk variabel dengan skala ordinal, hal ini tidak sesuai dengan syarat bahwa regresi linier variabel respon haruslah variabel kontinu seperti yang dikemukakan oleh (Kutner, et.al, 2005)

Dalam statistika hipotesis penelitian dirumuskan menjadi dua yaitu hipotesis nol $\left(\mathrm{H}_{0}\right)$ dan hipotesis alternatif $\left(\mathrm{H}_{1}\right)$. Untuk penelitian di atas kan lebih baik bila peneliti menggunakan pengujian hipotesis serentak dengan uji $\mathrm{F}$ untuk melihat apakah ketiga variabel prediktor secara bersama-sama berpengaruh terhadap variabel respon, dan menggunakan uji $-\mathrm{t}$ jika ingin dicari pengaruh variabel prediktor terhadap variabel 
respon secara individu dengan menganggap variabel lain konstan. Nilai statistik $F$ dan statistik. $t$ dapat dilihat langsung pada luaran software yang digunakan.

Berikut adalah metode statistika yang dapat digunakan sebagai pengganti kekurang tepatan penggunaan analisis regresi linier berganda.

Tabel 5 Metode yang Direkomendasikan Sebagai Pengganti Analisis Regresi Linier

\begin{tabular}{|c|c|}
\hline Jenis Variabel & Metode \\
\hline 1. Variabel respon dan variabel prediktor kategorik & 1. Log Linier Model \\
\hline $\begin{array}{l}\text { 2. Variabel respon dengan skala nominal, variable } \\
\text { prediktor gabungan skala ordinal, nominal, interval dan } \\
\text { rasio }\end{array}$ & $\begin{array}{l}\text { 2. Analisis Regresi Logis- } \\
\text { tik Biner atau Model } \\
\text { Logit }\end{array}$ \\
\hline $\begin{array}{l}\text { 3. Variabel respon skala nominal, variabel prediktor } \\
\text { gabungan skala ordinal, nominal, interval dan rasio }\end{array}$ & $\begin{array}{l}\text { 3. Analisis Regresi Logistik } \\
\text { multinomial }\end{array}$ \\
\hline $\begin{array}{l}4 \text { Variabel respon skala ordinal, variabel prediktor } \\
\text { gabungan skala ordinal, nominal, interval dan rasio }\end{array}$ & $\begin{array}{l}\text { 4. Analisis Regresi Logis- } \\
\text { tik Ordinal }\end{array}$ \\
\hline $\begin{array}{l}\text { 5. Variabel respon dan variabel prediktor dinyatakan } \\
\text { dengan beberapa indikator }\end{array}$ & $\begin{array}{l}\text { 5. Analisis Korelasi } \\
\text { nonik }\end{array}$ \\
\hline
\end{tabular}

2) Menarik kesimpulan hanya berdasarkan statistika deskriptif

Masih ada artikel yang menyimpulkan suatu perlakuan berbeda dengan perlakuan lain hanya berdasarkan nilai rata-rata yang berbeda tanpa diuji dulu kebenarannya secara statistika, atau menyimpulkan suatu perlakuan memberikan hasil yang lebih baik dari yang lain hanya berdasarkan diagram batang. Walaupun secara matematika rata-rata nilai dua perlakuan berbeda, belum tentu kedua perlakuan tersebut memberikan hasil yang berbeda secara signifikan

3) Menyimpulkan tidak ada korelasi antar dua variabel pada saat ditemukan nilai korelasi negatif. Nilai negatif bisa saja menunjukkan ada korelasi/hubungan antara variabel satu dengan yang lain tetapi dalam arah yang berlawanan. Secara teori korelasi bisa bernilai positif apabila perubahan pada variabel yang satu akan diikuti perubahan pada variabel yang lain secara teratur dengan arah yang sama atau bernilai nilai negative apabila perubahan pada variabel yang satu akan diikuti perubahan pada variabel yang lain dengan arah berlawanan.

4) Penggunaan uji Chi kuadrat untuk sampel berukuran kecil

5) Penggunaan uji-t dua sampel untuk pengamatan dengan skala ordinal. Syarat uji-t adalah sekurang-kurangnya data yang diamati dengan skala rasio.

6) Menggunakan ANOVA tanpa melakukan uji kenormalan dan uji homogenitas varian terlebih dahulu. Jika dalam uji kenormalan dan uji homogenitas varian kedua syarat tersebut tidak dipenuhi lebih tepat menggunakan uji Kruskal Wallis. 
Untuk megatasi kekeliruan penggunaan metode statistika pada penulisan artikel ilmiah (Bahar et al., 2018) merekomendasikan pemilihan metode statistika yang tepat sebagai berikut:

Tabel 6. Pemilihan Metode Statistika Berdasarkan Skala Pengukuran

\begin{tabular}{|c|c|c|c|}
\hline Variabel & $\begin{array}{l}\text { Pengukuran } \\
\text { (Asumsi normal) }\end{array}$ & $\begin{array}{l}\text { Pengukuran } \\
\text { berdasarkan } \\
\text { peringkat (Tanpa } \\
\text { asumsi normal) }\end{array}$ & Dikotomi \\
\hline $\begin{array}{l}\text { Ukuran } \\
\text { Pemusatan,penyebaran }\end{array}$ & $\begin{array}{l}\text { Mean, Standar } \\
\text { deviasi }\end{array}$ & $\begin{array}{l}\text { Median, jarak antar } \\
\text { kuartil }\end{array}$ & Proporsi \\
\hline $\begin{array}{l}\text { Membandingkan } 2 \\
\text { kelompok berpasangan }\end{array}$ & $\begin{array}{l}\text { Uji- } \mathrm{t} \text { sampel } \\
\text { berpasangan }\end{array}$ & $\begin{array}{l}\text { Uji U Mann- } \\
\text { Witney }\end{array}$ & $\begin{array}{l}\text { Uji exact } \\
\text { Fisher }\end{array}$ \\
\hline $\begin{array}{l}\text { Membandingkan } 2 \\
\text { kelompok independen }\end{array}$ & $\begin{array}{l}\text { Uji-t sampel } \\
\text { independen }\end{array}$ & $\begin{array}{l}\text { Uji Peringkat } \\
\text { bertanda Wilcoxon }\end{array}$ & $\begin{array}{l}\text { Uji } \\
\text { McNemar }\end{array}$ \\
\hline $\begin{array}{l}\text { Menbandingkan >2 } \\
\text { kelompok berpasangan }\end{array}$ & ANOVA & Uji Friedman & Uji Cohcran \\
\hline $\begin{array}{l}\text { Membandingkan }>2 \\
\text { kelompok independen }\end{array}$ & ANOVA & Uji Kruskal-Wallis & Uji $\chi^{2}$ \\
\hline Aosiasi/hubungan & $\begin{array}{l}\text { Korelasi } \\
\text { Pearson }\end{array}$ & Korelasi Spearman & $\begin{array}{l}\text { Uji } \\
\text { Cramer }\end{array}$ \\
\hline Prediksi suatu nilai & $\begin{array}{l}\text { Regresi } \\
\text { linier/regresi } \\
\text { non linier }\end{array}$ & $\begin{array}{l}\text { Nonparametrik } \\
\text { regresi }\end{array}$ & $\begin{array}{l}\text { Regresi } \\
\text { Logistik }\end{array}$ \\
\hline
\end{tabular}

Sumber:(Bahar et al., 2018)

\section{Kesimpulan dan Saran}

Masih ada kekeliruan penggunaan metode statistika pada artikel yang termuat pada jurnal OJS UNUD. Kekeliruan yang ditemukan diantaranya: penerapan metode regresi linier berganda pada data yang tidak kontinu, penggunaan ANOVA pada pengamatan dengan skala ordinal, uji t untuk data ordinal, penggunaan Chi kuadrat pada sampel kecil . Untuk mengurangi terjadinya kekeliruan penggunaan metode statistika yang berlarut-larut perlu dilakukan pelatihan-pelatihan penggunaan metode statistika yang tepat pada fakultas-fakultas yang sering melakukan penelitian kuantitatif.

\section{Ucapan Terima Kasih}

Penulis mengucapkan terima kasih kepada Rektor Universitas Udayana, serta Ketua LPPM Universitas Udayana yang telah memberikan dana penelitian dengan kontrak 
DIPA PNBP 2018 No: 5742.002.053.525119 tanggal pada 31 Maret 2018

\section{Daftar Pustaka}

Bahar, B., Pambuccian, S. E., Barkan, G., \& Akdas, Y. (2018). The Use and Misuse of Statistical Methods in Cytopathology Studies: Review of 6 Journals, 8-15. https://doi.org/10.1093/labmed/lmy036

Gardenier, J. S., \& Resnik, D. B. (2002). The Misuse of Statistics : Concepts, Tools, and a Research Agenda, 9(2).

Jeon, J. (2015). The Strengths and Limitations of the Statistical Modeling of Complex Social Phenomenon : Focusing on SEM, Path Analysis, or Multiple Regression Models. International Journal of Social, Behavioral, Educational, Economic, Business and Industrial Engineering, 9(5), 1634-1642.

Kutner, M. H., Nachtsheim, C. J., Neter, J., \& Li, W. (2005). Applied Linear Statistical Models (5th ed.). New York: McGraw-Hill.

Thiese, M. S., Arnold, Z. C., \& Walker, S. D. (2015). The misuse and Abuse of Statistics in Biomedical Research. Biochemia Medica, 25(1), 5-11. https://doi.org/10.11613/BM.2015.001

Wu, S., Jin, Z., Wei, X., Gao, Q., Lu, J., Ma, X., ... He, J. (2011). Misuse of Statistical Methods in 10 Leading Chinese Medical Journals in 1998 and 2008. The Scientific World Journal, 11, 2106-2114. https://doi.org/10.1100/2011/139494 